\title{
Human Impacts on the Nearshore Environment: An Archaeological Case Study from Kaua'i, Hawaiian Islands ${ }^{1}$
}

\author{
Alex E. Morrison ${ }^{2,3}$ and Terry L. Hunt ${ }^{2}$
}

\begin{abstract}
Archaeology provides a long-term framework to document prehistoric resource use and habitat modification. Excavation at Nu'alolo Kai, Kaua'i, yielded a large, well-preserved shellfish assemblage. Analysis determined the susceptibility of mollusk communities to human foraging pressures in the past. Some coral reef and intertidal species, such as Turbo sandwicensis and Strombus maculatus, declined in abundance as a result of heavy exploitation. In contrast, shoreline mollusk communities remained fairly stable through time. Archaeological research provides baselines for modern conservation efforts and fisheries management.
\end{abstract}

The oceans In their expanse over the globe provide over $99 \%$ of the habitable environment for life on our planet (Woodward 2000). Yet even this vast and once believed inexhaustible "last frontier" has suffered from cases of overexploitation, depletion, and even ecological collapse. With concerns of impending catastrophe, Woodward (2000) noted that marine biologists are frightened by the scale and complexity of the emerging crisis. Human influences are widespread, but the greatest impact has occurred in nearshore and coastal zones $(0-50 \mathrm{~m}$ in depth) in close proximity to the majority of the planet's human populations.

Although many impacts are recent, Jackson et al. (2001:629) argued that in a number of cases, "overfishing and ecological extinction predate and precondition modern ecological investigations and the collapse of marine ecosystems in recent times." Those authors pointed out the importance of historical data in better understanding the impacts

\footnotetext{
${ }^{1}$ Manuscript accepted 9 July 2006.

2 Department of Anthropology, University of Hawaici at Mānoa, 2424 Maile Way, Saunders Hall 346, Honolulu, Hawai'i 96822-2223.

${ }^{3}$ Correspondence: alexmorr@hawaii.edu.
}

Pacific Science (2007), vol. 61, no. 3:325-345

(C) 2007 by University of Hawai'i Press

All rights reserved of environmental disturbances, long-term human use, and postcolonial fisheries on marine ecosystems. Jackson (2001) and Jackson et al. (2001) showed how retrospective records from coastal ecosystems offer baselines that contrast with modern field studies. "We cannot generate realistic null hypotheses about the composition and dynamics of ecosystems from our understanding of the present alone, since all ecosystems have almost certainly changed due to both human and natural environmental factors" (Jackson et al. 2001:630).

Historical perspectives are essential not only for establishing baselines and providing a deeper view of ecosystem change, but also for constructing realistic models to serve conservation biology (Lyman and Cannon 2004). Discerning modern trends in many species is often hindered by a lack of knowledge concerning prehistoric human impacts and other relevant factors that may have contributed to the current demography of these resources (Wing and Wing 2001, Butler and Delacorte 2004).

In the Hawaiian Islands, catch records for the endemic shellfish 'opibi (Cellana spp.) show that since approximately 1900 humaninduced pressures from heavy fishing have led to a substantial decrease in the abundance of these shoreline fauna (Cobb 1905, Kay and Magruder 1977). Consequently, legislation was developed in the late 1970s to enforce 'opibi fishing regulations (Hawai'i Department of Land and Natural Resources 1981). However, these regulative measures have 
failed to take into consideration the longterm historical perspective offered by archaeology.

Here we develop a case study of human predator-prey relations for a marine ecosystem over the long-term historical frame provided by archaeology. Our research examines approximately $600 \mathrm{yr}$ of shellfish exploitation from Nu'alolo Kai, Kaua'i, extending records of 'opibi and other mollusk species use centuries before historic documentation. We believe that zooarchaeological and paleoecological analyses are invaluable for properly modeling ecosystem change and habitat management (Lyman and Cannon 2004). Analyzing an archaeological assemblage of shellfish from a dated, stratified context, we use foraging theory models to test hypotheses for human-induced resource change. By applying formal modeling developed specifically to examine spatial and temporal patterns in resource use, this study is able to gain finegrained resolution regarding habitat exploitation and human impacts.

\section{Background}

Over the past several decades, archaeologists, anthropologists, and others have written about indigenous societies as conservationists inhabiting pristine environments, or as agents of widespread impacts and wholesale habitat destruction (Kirch 1997, Smith and Wishnie 2000). The latter perspective has recently been popularized and perhaps sometimes exaggerated (e.g., Diamond 2005). A dichotomy of conservation and wholesale destruction oversimplifies the complexity of human predator-prey relationships in the historical context of marine environments.

Several studies provide evidence for the nature and extent of human impacts on marine ecosystems, including overfishing and its consequences (e.g., Hildebrandt and Jones 1992, Butler 2000, Grayson 2001, Mannino and Thomas 2001, 2002, Lyman 2003, Erlandson et al. 2004, Reitz 2004, Steneck et al. 2004). In the Pacific Islands, Swadling (1976, 1986), Anderson (1981), Kirch and Yen (1982), Allen (1992, 2002, 2003), Butler
(2001), Thomas (2001, 2002), and McAllister (2003), among others, have provided the details of fish and shellfish use, including cases of relative resource stability or depression and habitat structure modification. However, despite the importance of shellfish in traditional Pacific Island subsistence, few studies have addressed the question of human impacts, including resource depression, on shellfish populations in the past. Two recent studies by Thomas $(2001,2002)$ show the promise of studying archaeological marine mollusk assemblages from Pacific islands. Documenting human predator-prey relations with these often-abundant, protein-rich resources has important implications for other aspects of subsistence change in the Pacific islands.

\section{Evolutionary Ecology, Foraging Theory, and Resource Depression}

As a theoretical framework, evolutionary ecology allows us to test predictions regarding human behavior in a variety of ecological contexts. Predictions are typically derived from formal optimization models. The logic of foraging theory and other evolutionary ecology models is based on fundamental concepts in Darwinian evolution (Pianka 1983).

Foraging models are usually constructed in three parts: decisions, currencies, and constraints (Stephens and Krebs 1986). Decisions are the alternative choices an individual faces while foraging, such as which resources should be pursued while others are ignored. Once an item is chosen for processing and consumption, other prey are excluded. In foraging theory, the decision component refers to criteria that are important to prey choice. Examples of these criteria are prey size, location, and ease of capture.

To evaluate the likelihood of alternative decisions, a currency must be added to the model as a measurement scale. The most common currency used in foraging models is net energy gained foraging $(R)$, which can be expressed as the energy acquired from a prey item per unit of time spent foraging $\left(F_{t}\right)$. Foraging time equals the time spent search- 
ing for a prey $\left(T_{s}\right)$, plus the time spent handling the item $\left(T_{b}\right)$. For archaeological studies, Broughton $(1994,2001)$ suggested that prey size can be used as an approximation for energy gained per item $\left(E_{f}\right)$. The currency rate $(R)$ can be expressed as:

$$
R=E_{f} /\left(T_{s}+T_{b}\right)
$$

Measuring foraging time directly in archaeological applications is impossible because search time $\left(T_{s}\right)$ and handling time $\left(T_{b}\right)$ cannot be observed. Anderson (1981) noted that for shellfish studies this does not present a substantial problem because mollusks are relatively immobile and usually processed using similar roasting methods. Consequently, individual foragers are likely to expend the same amount of energy searching $\left(T_{s}\right)$ and handling $\left(T_{b}\right)$ prey regardless of their species. If search time and handling time are assumed equal for all items, then the denominator of equation 1 is irrelevant and the new equation becomes:

$$
R=E_{f}
$$

Moreover, because an approximation for caloric energy gained per prey item $\left(E_{f}\right)$ is the size of the prey, the currency rate $(R)$ is simply equal to the size of the resources.

In many ecological and archaeological studies potential prey are ranked according to the energy returned upon consumption of the item. Although in most archaeological applications size is used as an approximation for energy gained per unit of time spent foraging, in many coastal contexts prey can potentially be captured en masse. When prey are mass captured, the acquired energetic unit becomes the group of items rather than the individual (Madsen and Schmitt 1998, Nagaoka 2002, Butler and Campbell 2004, Ugan 2005). Consequently, taking of prey items through mass-harvesting techniques may actually result in a higher harvesting return rate than when they are acquired individually. Changes in technology can also substantially affect harvesting rates by decreasing handling time and effort (Winterhalder 1981) and therefore should be assessed by looking at the faunal remains in combination with artifact distributions.

According to the prey choice model, foragers should include various prey types in the optimal diet breadth as long as those items have a net energy return $(R)$ greater than the average return rate of higher-ranked items. If the abundance of these items does not change and technological innovations do not occur, foraging return rates should remain stable. Because changes in prey choice are dependent upon the encounter rates of high-ranked items, when these items decrease in abundance foragers may choose a wider array of lower-ranked items and foraging efficiency will subsequently decrease.

Decreases in the encounter rates of highranked items may be caused by a number of factors. Environmental perturbations, such as climate change and natural and/or humaninduced habitat modification, can potentially affect the distribution of prey species, ultimately decreasing the encounter rates of high-ranked items (Byers and Broughton 2004, Wolverton 2005). More-favorable climatic conditions may also lead to higher abundances of certain species, leading to an increase in foraging efficiency.

Human exploitation can result in declining prey encounter rates as well. Resource depression due to overexploitation occurs when diminishing high-ranked prey leads foragers to rely on smaller, more-diverse, less-profitable items (Grayson 2001). To demonstrate adequately that changes in prey encounter rates were caused by human predation, it is necessary to rule out the possibility of either environmental change or new technologies as important factors. In coastal environments, sea-level fluctuations, coastal reconfigurations, and geomorphologic changes can depress mollusk populations (Butler and Campbell 2004; A.E.M. and E. E. Cochrane, unpubl. data). In the absence of any well-documented paleoenvironmental records showing dramatic change for $\mathrm{Nu}^{6}$ alolo Kai over the last $600 \mathrm{yr}$, we must assume that declining abundance is best explained by human foraging rather than environmental factors. 
Prey species are often located in spatially distinct clumps, referred to as patches (or habitats). Increased hunting within resourcerich habitats can result in declining prey abundance and greater foraging effort in lessprofitable areas. The patch choice model and the marginal value theorem predict that as productive habitats decrease in overall prey return rate, foragers will begin using lessproductive areas (Charnov 1976). Consequently, the ratio of taxa from productive to less-productive habitats may indicate shifts in patch exploitation.

The prey and patch choice models provide some predictions for subsistence patterns. First, decreases in the abundance of largebodied prey and increases in smaller prey signify declining foraging efficiency. Because items with high energetic returns are likely taken upon encounter, an increase in relative abundance of less-profitable items signifies diminishing foraging return rates. At Nu'alolo Kai, tracking the relative relationship between large-bodied and small-bodied mollusk species is a useful method for measuring foraging efficiency. Consequently, if decreased foraging efficiency occurs, a general increase in the relative abundance of small-bodied mollusks should be quantifiable.

Second, as foraging efficiency declines substantially, the diet breadth may widen enough that pursuing lower-ranked items upon encounter becomes advantageous. In this situation the subsistence routine expands to include a more-diversified, generalized diet. However, it is possible that foraging efficiency may decline without leading to changes in diet breadth, particularly in situations where processing and harvesting lowerranked items do not result in a high mean return rate. In the study reported here, richness and evenness analyses were used to assess changes in diet breadth at Nu'alolo Kai. Finally, declines in foraging efficiency may lead to the inclusion of lower-ranked habitats where smaller-bodied mollusk species are found. According to the patch choice model (Charnov 1976, Orians and Pearson 1979), if the mean foraging return rate of high-ranked habitats decreases extensively, patches that were formerly less advantageous will be foraged more often.

\section{MATERIALS AND METHODS}

\section{The Nu'alolo Kai Excavation}

Nu'alolo Kai is located along the north shore of Kaua'i Island (Figure 1) in close proximity to a highly productive marine ecosystem that includes a fringing coral reef community.

At Nu'alolo Kai there are several archaeological sites attesting to the location's longterm prehistoric occupation. In particular, ancient constructed terraces protected by a massive rock overhang have been the focus of extensive archaeological research. From 1958 to 1964, Kenneth Emory and his associates conducted large-scale excavations and recovered thousands of well-preserved artifacts (see Graves et al. 2005 for an overview). Although these finds are important, the standards of excavation were not the same as those today, and many of the assemblages, including some shellfish, present problems for any quantitative analyses. In an effort to recover comparable materials under modern excavation and collection standards, one of us (T.L.H.) directed fieldwork at Nu'alolo Kai in 1990 (see Hunt 2005 for a summary).

In 1990 T.L.H. excavated a 2 by $1 \mathrm{~m}$ unit at Site K3 in an area not previously excavated (details provided in Hunt 2005). Excavation yielded an abundance of shell, other fauna, and macrobotanical remains, as well as an abundance of artifacts. A.E.M. identified and analyzed the shellfish assemblage reported here. The 1990 excavations also resulted in a new suite of radiocarbon dates. T.L.H.'s excavation offers the possibility to understand temporal patterns in mollusk use because of the large amount of shellfish remains, the excellent preservation, and the chronological control. New research can provide a deeper understanding into this remarkable archaeological deposit.

\section{Chronology}

Five samples of wood charcoal submitted from the deepest levels of Emory's early ex- 


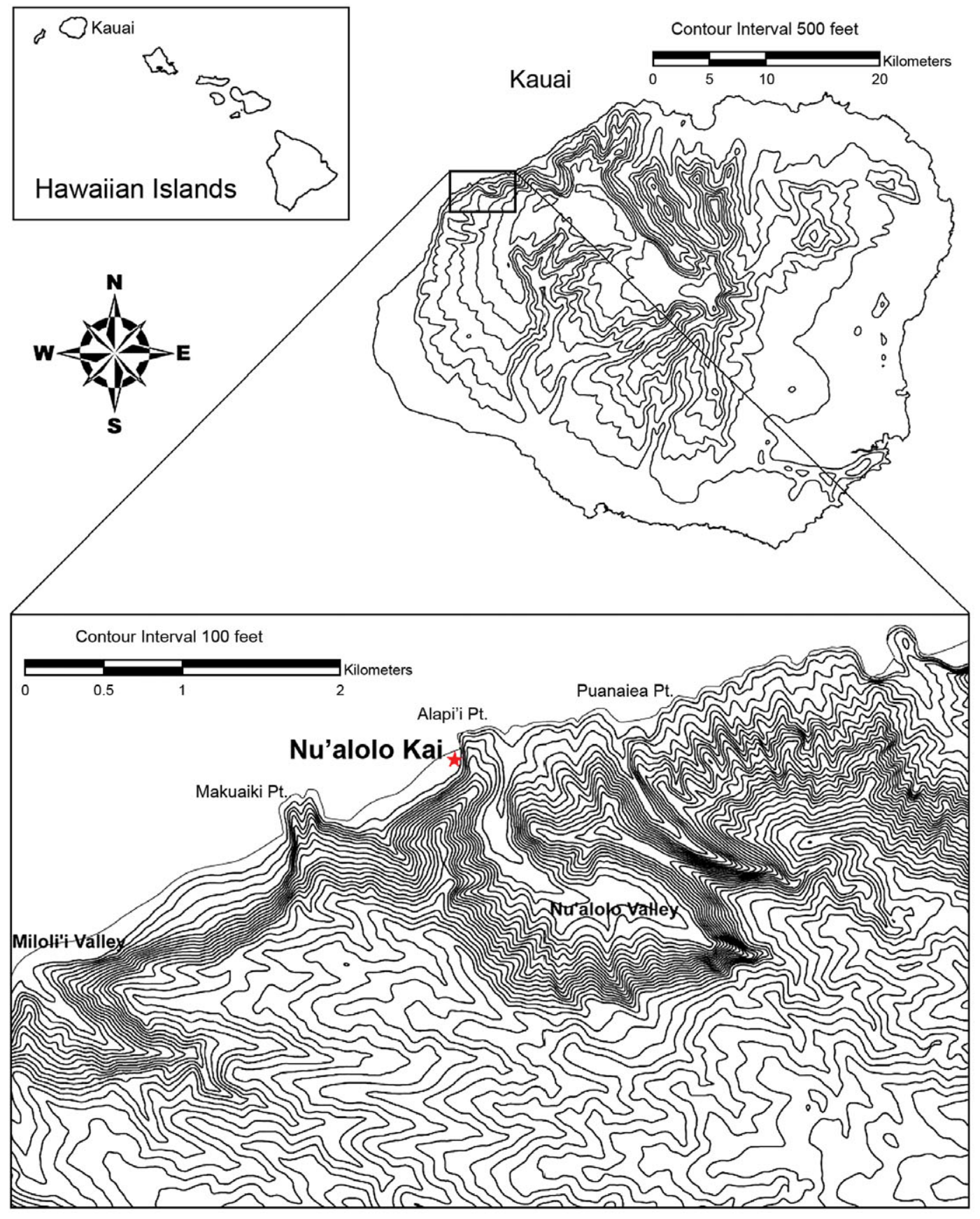

Figure 1. Map of Kaua'i with location of Nu'alolo Kai on northern coast (adapted from Esh 2005). 


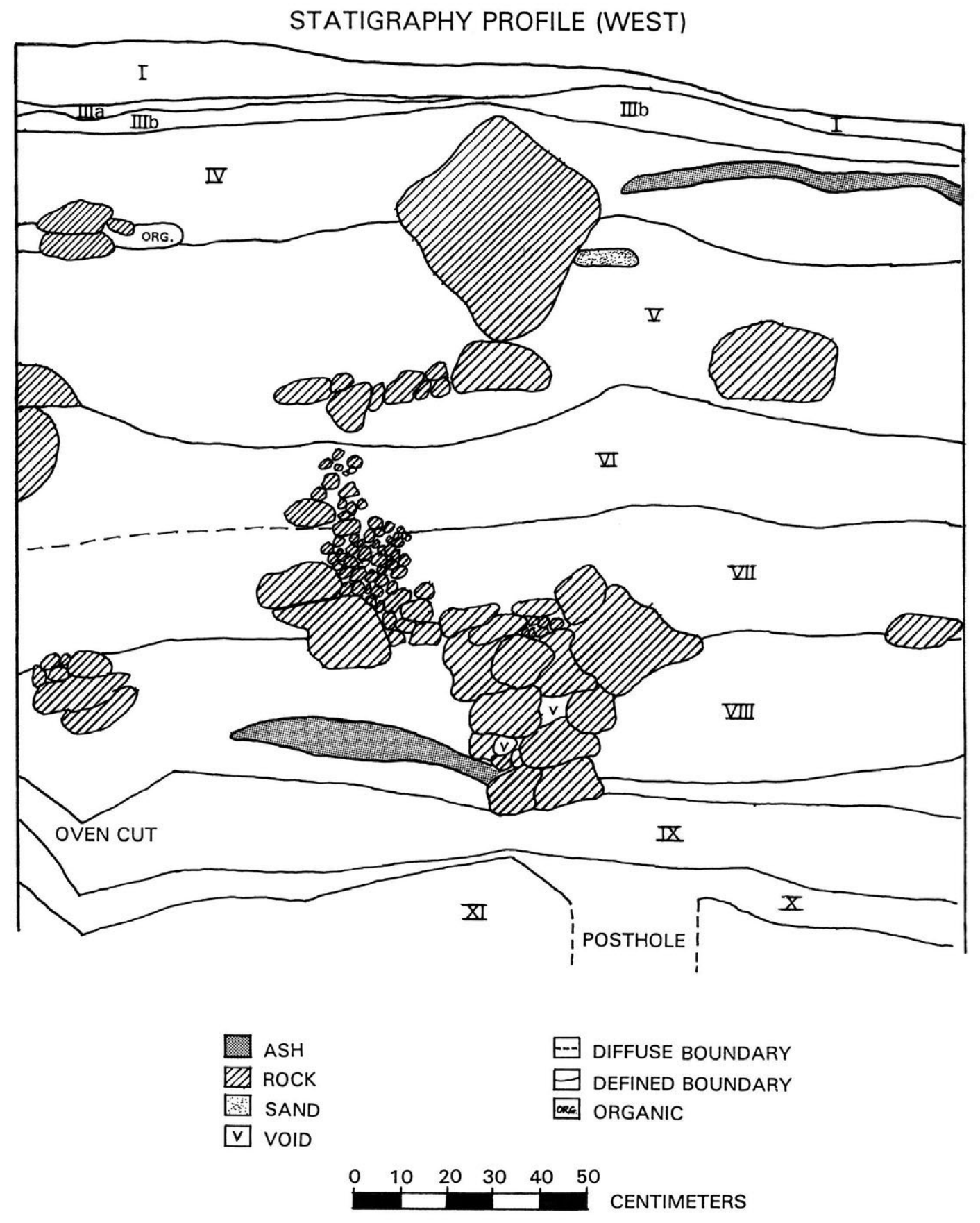

Figure 2. West wall of Nu'alolo Kai excavation. 
TABLE 1

Relationship between Radiocarbon Dates and Analytic Units Developed for the Analysis

\begin{tabular}{llll}
\hline \hline Analytic Unit & \multicolumn{1}{c}{ Dates (Interval) } & \multicolumn{1}{c}{ Date } & \multicolumn{1}{c}{ Period } \\
\hline Zone A & Present-(1860-1740) & $1800-$ present & Protohistoric-Historic \\
Zone B & $(1860-1740)-(1620-1520)$ & $1570-1800$ & Late Prehistoric-Protohistoric \\
Zone C & $(1620-1520)-(1470-1350)$ & $1410-1570$ & Prehistoric \\
\hline
\end{tabular}

cavations have suggested to some a chronology of occupation at Nu'alolo Kai that began in the twelfth century (Kirch 1985). However, concluding that the rockshelter dates to the twelfth century places great faith in a single radiocarbon date $(\mathrm{GaK}-1343,840 \pm 70$ B.P.). As Hunt (2005:253) pointed out, many would reject this date because it has never been replicated in additional dates from similar stratigraphic context of the same deposit. Four other radiocarbon determinations from the deepest cultural context of the deposit overlap at one standard deviation, placing the earliest occupation of Nu'alolo Kai Rockshelter between about A.D. 1300 to 1500 (calibrated [see Hunt 2005]).

From the fieldwork of 1990 T.L.H. selected four wood charcoal samples from secure stratigraphic contexts (Figure 2, Layers $\mathrm{X}$ and $\mathrm{XI}$ ) and submitted them to Beta Analytic. The results provide a chronology that suggests that initial occupation at Nu'alolo Kai began around cal A.D. 1400 (with materials in Layer XI). The age of Layer X (three dates) may extend to cal A.D. 1600 or later. The dates for Layer $\mathrm{X}$ suggest that the remaining layers of the deposit formed over a period of about $200 \mathrm{yr}$. Historic artifacts of Layers IV-V represent the beginning of effective European contact, in this area of Kaua'i, probably after A.D. 1800 . In sum, the chronology of occupation at Nu'alolo Kai may have an early beginning at around A.D. 1400 , but much of the cultural deposit dates to later times (after A.D. 1600 [Table 1, Figure 3]).

\section{Aggregation and Sample Size}

In the $1990 \mathrm{Nu}$ 'alolo Kai excavation, 11 stratigraphic layers were excavated in arbitrary levels to provide minimal analytic units

Atmospheric data from Reimer et al (2004); Oxcal v3.10 Bronk Ramsey (2005); cub r. 5 sd: 12 prob usp[chron]

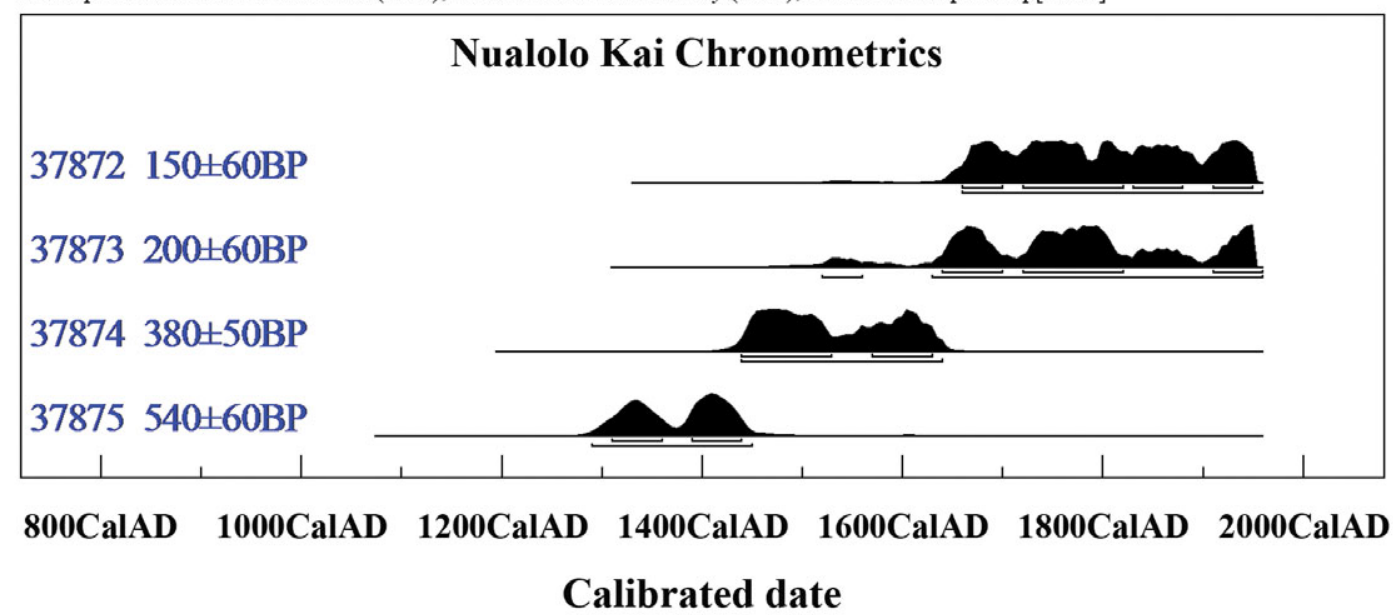

FIgURE 3. Probability distribution for four calibrated dates from Nu'alolo Kai. 
TABLE 2

Shellfish Weight in Grams by Natural Stratigraphic Units

\begin{tabular}{lc}
\hline \hline Stratigraphic Unit & Shellfish Weight $(\mathrm{g})$ \\
\hline I & 736.61 \\
II & 476.91 \\
III & $1,762.112$ \\
IV & $2,941.22$ \\
V & $3,843.7$ \\
VI & $2,254.31$ \\
VII & $1,413.73$ \\
VIII & $2,331.92$ \\
IX & $2,418.9$ \\
X & $11,618.2$ \\
XI & $16,283.4$ \\
Total & $46,081.012$ \\
\hline
\end{tabular}

for analysis (Table 2). Although fine-grained temporal divisions would have been ideal, several issues regarding sample size emerged. Analyses looking at the diversity of species and the relative proportions of prey items may be seriously affected by differing sample sizes (Grayson 1984). For example, measures of relative abundances are often strongly correlated with the size of the subsamples from which they were derived. This is particularly true when the assemblage is dominated by small and dramatically varying sample sizes.

When aggregated by natural stratigraphic layers, sample size is positively correlated with relative abundance in several important mollusk species. For example, as the size of the sample increased, so did the relative abundance of Turbo sandwicensis $\left(r_{s}=.909\right.$ sig $<.000)$ and Nerita picea $\left(r_{s}=-0.836\right.$, $P<.001)$. To solve this problem, we combined samples from aggregations of layers to form assemblages (analytical units) of near equal sizes. Combining these layers into larger assemblages decreased the significant correlation (Turbo sandwicensis $r_{s}=0.5, P=$ .667 ; Nerita picea $\left.r_{s}=0.5, P=.667\right)$. Although analyzing each layer independently would have created a greater number of comparative points, the strong positive correlation between sample size and prey relative abundance would have limited the reliability of our results and obscured the cause of these
TABLE 3

Revised Analytic Aggregates after Dealing with Sample Size Issues

\begin{tabular}{llc}
\hline \hline $\begin{array}{l}\text { Time } \\
\text { Period }\end{array}$ & $\begin{array}{c}\text { Stratigraphic } \\
\text { Unit }\end{array}$ & $\begin{array}{c}\text { Shellfish } \\
\text { Weight }(\mathrm{g})\end{array}$ \\
\hline Zone A & Layer I-VIII & $15,760.5$ \\
Zone B & Layer IX-X & $14,037.1$ \\
Zone C & XI & $16,283.4$ \\
\hline
\end{tabular}

patterns. A potential drawback when collapsing stratigraphic layers into larger analytic units is that the analyst must rely on fewer data points for comparative analyses. This can be problematic when assessing trends on a quantitative scale. However, we opted for greater confidence in our results at the expense of a large number of comparative units. The final analytic units are listed in Table 3 and these correspond to the temporal designations shown in Table 1.

\section{Comparative Indices and Resource Depression}

To test the hypothesis that foraging pressure resulted in resource depression we first compared changes in the amount of large-bodied versus small-bodied prey items within each of two habitat types. In this paper we use comparative indices to track these relationships.

$$
\begin{gathered}
\sum \text { large taxon } / \sum \text { (large taxon } \\
+ \text { small taxon })
\end{gathered}
$$

Nagaoka (2002) employed comparative indices in her study of New Zealand foraging patterns. Index values simply turn the ratio of a large to small-sized taxa into an easily tractable number between 1 and 0 . High index values (close to 1) reflect higher proportions of larger items, and a smaller index value indicates decreasing foraging efficiency (Nagaoka 2002). Using an assemblage from the Shag Mouth site, Nagaoka documented a decrease in the moa-quail index from 1.0 at level 10 to 7.5 later in the sequence. Thus, as large moa were declining, smaller quail were being taken more often. 
TABLE 4

Coral Reef Mollusk Species Recovered from the Nu'alolo Kai Excavation

\begin{tabular}{|c|c|c|c|c|c|}
\hline \multirow[b]{2}{*}{ No. } & \multirow[b]{2}{*}{ Species } & \multicolumn{4}{|c|}{ Coral Reef Species } \\
\hline & & Zone A & Zone B & Zone C & Total \\
\hline 1 & Turbo sandwicensis & $2,926.50$ & 7,244 & 10,296 & $20,466.5$ \\
\hline 2 & Strombus maculatus & $3,193.01$ & $3,676.5$ & $2,879.8$ & $9,749.31$ \\
\hline 3 & Isognomon sp. & $2,205.10$ & $1,132.9$ & $1,102.2$ & $4,440.2$ \\
\hline 4 & Cypraea spp. & 720.3 & 169.2 & 254.1 & $1,143.6$ \\
\hline 5 & Conus spp. & 623.9 & 219.1 & 56.2 & 899.2 \\
\hline 6 & Periglypta reticulata & 158.52 & 144.2 & 48 & 350.72 \\
\hline 7 & Trochus intexus & 47.31 & 135.2 & 129.7 & 312.21 \\
\hline 8 & Rbynoclavis sp. & 13.9 & - & 35.8 & 49.7 \\
\hline 9 & Tellina spp. & - & 33.7 & - & 33.7 \\
\hline 10 & Codakia punctata & 19.4 & - & - & 19.4 \\
\hline 11 & Thais intermedia & 15.4 & - & - & 15.4 \\
\hline 12 & Modulus tectus & - & - & 14.7 & 14.7 \\
\hline 13 & Vexillum sp. & - & 10.9 & - & 10.9 \\
\hline 14 & Tellina sp. & 10.8 & - & - & 10.8 \\
\hline 15 & Hydantia sp. & 4.6 & - & - & 4.6 \\
\hline 16 & Umbraculum sp. & 0.01 & - & - & 0.01 \\
\hline 17 & Anadara sp. & 0.01 & - & - & 0.01 \\
\hline 18 & Tracbycaridum sp. & 0.01 & - & - & 0.01 \\
\hline \multirow[t]{2}{*}{19} & Cerithium sp. & 0.01 & - & - & 0.01 \\
\hline & Total & $9,938.78$ & $12,765.7$ & $14,816.5$ & $37,520.98$ \\
\hline
\end{tabular}

Note: Recorded by shell weight in grams ( 0.01 indicates presence but negligible weight).

\section{Patch Classification}

A limitation of the prey choice model is the assumption that all prey items are searched for simultaneously. However, in many circumstances, foragers allocate time in specific patches and therefore do not search for all available prey species in the environment at one time. Smith (1991) suggested that to solve this problem it is necessary to apply the prey choice model within patches. This creates the possibility for analyzing encounter rates within spatially distinct habitats. For Nu'alolo Kai, we used two habitat classifications based on prey locations: the shoreline and coral reef patches (Tables 4 and 5).

The statistical methods used in the analysis consist of Spearman Rank Order Correlation Coefficient, which is a nonparametric test applied to ordinal data. This test is commonly applied to archaeological data that are ordinal rather than interval, small sample sizes, or not normally distributed.

We also used Cochran's test of linear trend to test for a significant tendency in the relationship between large- and small-bodied prey. Cochran's test for linear trend is a chisquare test comprising three components: a traditional chi-square test that tests the overall relationship between the two variables, the variation as a result of a linear trend, and the departure from the linear trend.

\section{RESULTS}

\section{Foraging Efficiency in the Coral Reef Patch}

When compared by prey size, Turbo sandwicensis is the largest coral-reef taxon, with an average size of $90 \mathrm{~mm}$ (Severns 2001). In contrast, another abundant yet smaller prey item is Strombus maculatus, which has an average size of $32 \mathrm{~mm}$ (Severns 2001). If foraging efficiency declined in the coral reef patch there should be a measurable decrease in the relative relationship between Turbo sandwicensis and Strombus maculatus, indicated by declining index values.

Figure 4 demonstrates a decrease in the proportion of the large Turbo sandwicensis 
TABLE 5

Shoreline Mollusk Species Recovered from the Nu'alolo Kai Excavation

\begin{tabular}{|c|c|c|c|c|c|}
\hline \multirow[b]{2}{*}{ No. } & \multirow[b]{2}{*}{ Species } & \multicolumn{4}{|c|}{ Shoreline Species } \\
\hline & & Zone A & Zone B & Zone C & Total \\
\hline 1 & Cellana spp. & $2,553.4$ & 414.2 & 652.9 & $3,620.5$ \\
\hline 2 & Nerita picea & $2,447.3$ & 426.5 & 520.3 & $3,394.1$ \\
\hline 3 & Drupa ricina & 206.5 & 123.7 & 59.4 & 389.6 \\
\hline 4 & Morula sp. & 207.4 & 39.6 & 83.1 & 330.1 \\
\hline 5 & Littorina spp. & 116.9 & 47.4 & 22.5 & 186.8 \\
\hline 6 & Purpura aperta & 26.2 & - & 27.5 & 53.7 \\
\hline \multirow[t]{2}{*}{7} & Hipponix foliaceus & 15.9 & - & 3.8 & 19.7 \\
\hline & Total & $5,573.6$ & $1,051.4$ & $1,369.5$ & $7,994.5$ \\
\hline
\end{tabular}

Note: Recorded by shell weight in grams ( 0.01 indicates presence but negligible weight).

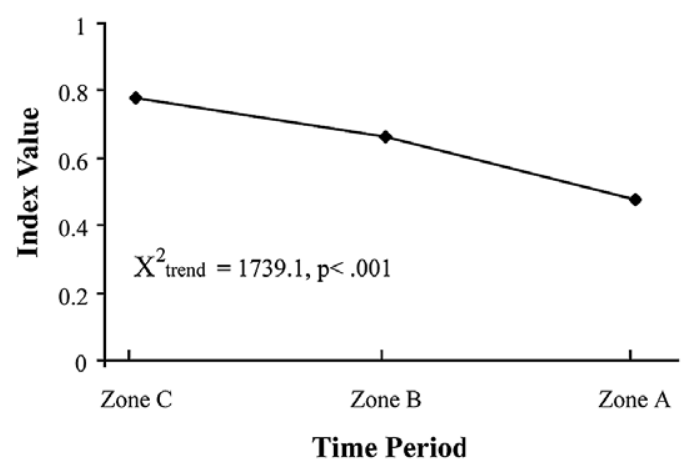

Figure 4. Coral reef patch comparative index values measuring the relative relationship of Turbo sandwicensis and Strombus maculatus.

relative to the smaller Strombus maculatus $\left(X_{\text {trend }}^{2}=1,739.1, P<.001\right)$. Weight measurements also support this conclusion, with a substantial decrease in Turbo sandwicensis across the three analytic zones (Table 6).

The archaeological evidence suggests that initially within the coral reef patch, foragers were relying predominately on Turbo sandwicensis to the near exclusion of other taxa. Over time Turbo sandwicensis declined substantially, and Strombus maculatus increased during the late prehistoric period and remained fairly stable. The decreasing index values are indicative of a decline in foragers relying on Turbo sandwicensis.

\section{Foraging Efficiency in the Shoreline Patch}

Of the two patches, shoreline mollusks are the smallest, with most of the represented taxa having a mean size of under $15 \mathrm{~mm}$. Thus, judging by prey size alone the shoreline patch appears to have the lowest overall foraging return rate of the two habitats in this analysis. The limpets Cellana spp. ('opibi) are the largest prey species in the shoreline habitat (Kay 1979). In contrast, Nerita picea is a smaller prey, with a mean size of $14 \mathrm{~mm}$.

The index values for the shoreline patch do not suggest resource depression (Figure

TABLE 6

Absolute Abundance of Turbo sandwicensis and Strombus maculatus by Weight (Grams) from Zone A to Zone C (Abundance Results Confirm Results from the Comparative Indices)

\begin{tabular}{llccc}
\hline \hline Species & Zone A & Zone B & Zone C & Total \\
\hline Turbo sandwicensis & $2,926.5$ & $7,244.0$ & $10,296.1$ & $20,466.5$ \\
Strombus maculatus & $3,193.01$ & $3,676.5$ & $2,879.8$ & $9,749.31$ \\
\hline
\end{tabular}




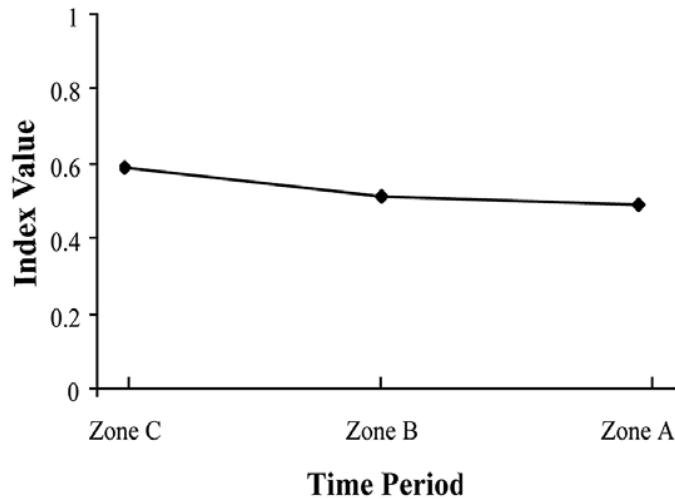

FIGURE 5. Shoreline patch comparative index values measuring the relative relationship between Cellana spp. and Nerita picea.

TABLE 7

Absolute Abundance of Cellana spp. and Nerita picea

\begin{tabular}{lcccc}
\hline \hline Species & Zone A & Zone B & Zone C & Total \\
\hline Cellana spp. & $2,553.4$ & 414.2 & 652.9 & $3,620.5$ \\
Nerita picea & $2,447.3$ & 426.5 & 520.3 & $3,394.1$ \\
\hline
\end{tabular}

5). Foraging return rates remained fairly stable through time. There is only a very slight drop in the index value during the late prehistoric period. A lack of evidence for resource depression is also supported by weight measurements (Table 7).

As Table 5 shows, all but one shoreline species increase dramatically up until the protohistoric period. The increase in the prevalence of shoreline species correlates with a decrease in important coral reef taxa, such as Turbo sandwicensis and Strombus maculatus. Based solely on the prey choice index analyses from the coral reef and shoreline habitats, it appears that by the late prehistoric period, resource depression had occurred in the coral reef patch. However, because temporal patterns in habitat use are closely tied to both the productivity of the habitat being foraged and the productivity of nearby habitats, it is important to look also at the relative contribution of prey species by habitat.

\section{Evaluating Changes in Habitat Use}

As foraging efficiency within a given patch declines to a point equal to or below the return rate for other exploitable patches, habitats will be added into the subsistence routine (Charnov 1976, Broughton 2001, Nagaoka 2002). At Nu'alolo Kai this should be reflected in a shift from foraging in the coral reef patch to the shoreline habitat. To test this hypothesis it is useful to create comparative indexes between items that are found in each habitat.

$$
\begin{gathered}
\sum(\text { coral reef taxa }) / \sum(\text { shoreline } \\
+ \text { coral reef taxa })
\end{gathered}
$$

The results from the patch choice analysis demonstrates that foragers relied substantially on the coral reef patch during the prehistoric and late prehistoric period, and then began more use of the shoreline patch during the protohistoric period (Figure 6). Cochran's test for linear trend supports this conclusion $\left(X_{\text {trend }}^{2}=4,071.98, P<.001\right)$.

Both the prey and patch indices suggest a decrease in the use of the coral reef patch. Accordingly, the shoreline patch appears to have been utilized substantially more by the protohistoric period. All but one shoreline species increased in abundance. Consequently, the use of the shoreline patch was relatively stable through time.

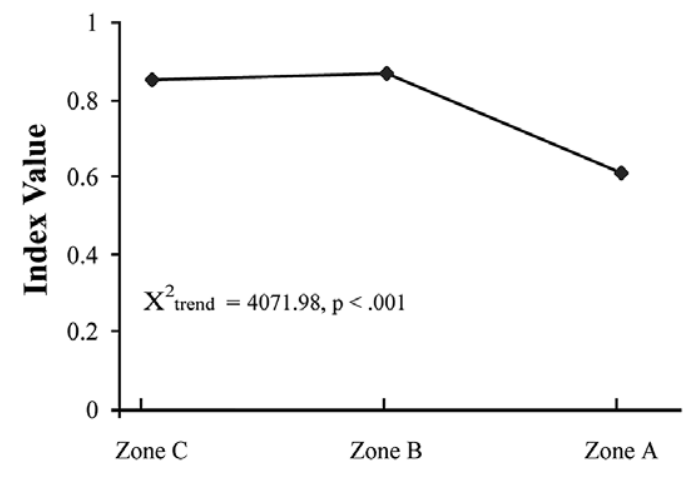

Time Period

Figure 6. Habitat comparative index values measuring the relationship between coral reef species and shoreline species. 
To provide more corroborative evidence for the trends measured by the prey and patch choice analyses, we also analyzed temporal patterns in assemblage diversity. Diversity measurements document changes in the number of taxa in the diet breadth as well as measure the proportional contribution of individual taxa to the entire assemblage.

\section{Prey Diversity and Foraging Efficiency}

Archaeologists commonly use two different means for measuring prey diversity. The first tracks the expansion of diet breadth by comparing the number of taxa (NTAXA) by time period. A more-diversified, generalized diet breadth should show an increase in NTAXA. The second measure of prey diversity is evenness. Evenness is a more-sophisticated measure because it quantifies the proportional relationships among species, rather than focusing simply on the number of taxa present.

The total assemblage shows evidence for increased taxonomic richness during the protohistoric period (Figure 7). Both the prehistoric and late prehistoric deposits contain 17 taxa, but the protohistoric deposits include 28 taxa. To determine if expanding diet breadth is a general trend or occurs only within distinct habitats, we also assessed taxonomic richness for both the shoreline and coral reef patches.

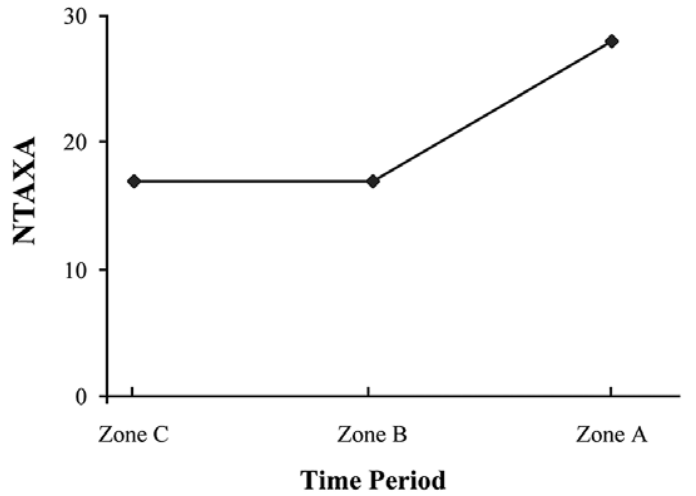

Figure 7. Number of taxa (NTAXA) from the entire assemblage, indicating an increase in prey diversity during the protohistoric period.

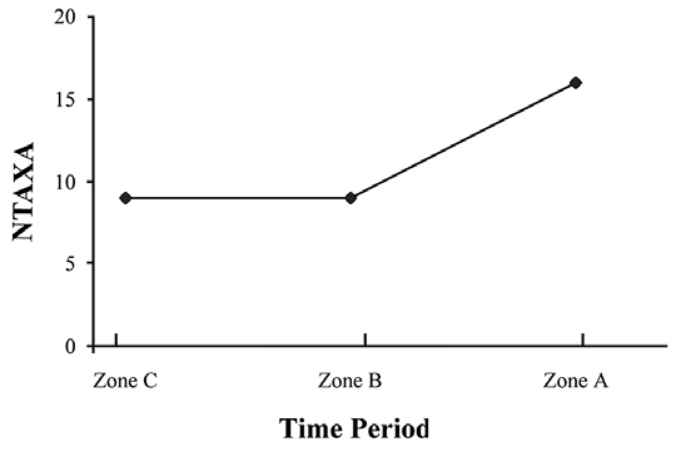

Figure 8. Number of taxa (NTAXA) from the coral reef patch, indicating an increase in prey diversity during the protohistoric period.

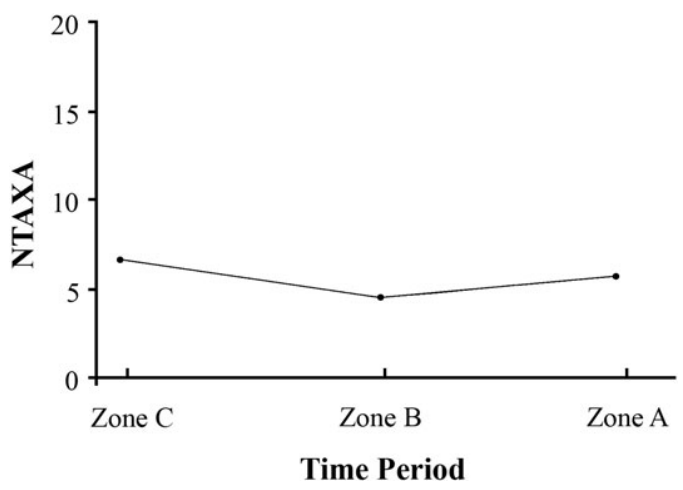

FIgURE 9. Number of taxa (NTAXA) from the shoreline patch, indicating stability in prey diversity.

The evidence from the coral reef patch supports the trend from the entire assemblage (Figure 8). During the prehistoric and late prehistoric periods diet breadth was relatively stable. However, in the protohistoric deposits there is an increase in NTAXA from 9 to 16 items. The NTAXA assessments from the shoreline patch document a different trend (Figure 9). Diet breadth in the shoreline patch begins with seven prey items and then drops to five during the late prehistoric. By the protohistoric period there are seven items present again. Accordingly, diet breadth did not change substantially in the shoreline patch.

Measurements of NTAXA are limited because they do not reflect the contribution of individual taxa to the entire assemblage. For 
example, the inclusion of more species into the diet is evidence for an expanding diet breadth, but no details on the relative contribution of specific taxa are taken into consideration. An assemblage dominated by a few abundant taxa will have a low measure of evenness. In contrast, when all taxa are present in near-equal amounts, the assemblage is considered highly even. Measurements of evenness can supplement diet breadth analysis by offering researchers the ability to track the relative importance of specific species through time. As diet breadth expands to include new items, it is necessary to look at the contribution of these taxa to the assemblage.

In many ecological and archaeological studies Shannon's Index is used to calculate evenness (Grayson 1984, Claassen 1998, Grayson and Delpech 1998, McAlister 2003). Shannon's Evenness Index $(E)$ is calculated as:

$$
\begin{aligned}
& \text { Evenness }=-\sum\left(p_{i} \log \left[p_{i}\right]\right) / \log (\mathrm{NTAXA}) \\
& \text { (where } p_{i} \text { is the proportional } \\
& \text { contribution of each item) }
\end{aligned}
$$

The corresponding value will be between 0 and 1 . A value of 0 demonstrates an assemblage with only a single taxon present, and a value of 1 indicates that all items are represented in equal amounts. In contrast to the indices used for measuring prey choice, an increase in evenness (and consequently evenness index values) indicates resource depression. Because large prey items are declining in abundance, the assemblage will incorporate a higher number of small less-profitable taxa. The result will be a more even assemblage.

When the entire shellfish assemblage is taken into consideration, evenness increases significantly through time $\left(r_{s}=1.00, P<\right.$ .001 [Figure 10]). However, as with NTAXA, it is useful to calculate evenness indices based on separate habitat types to gain spatial clarity.

The evenness index values for the coral reef patch are similar to the results from the entire assemblage (Figure 11). There is a general trend toward increasing evenness through time $\left(r_{s}=1.00, P<.001\right)$. In con-

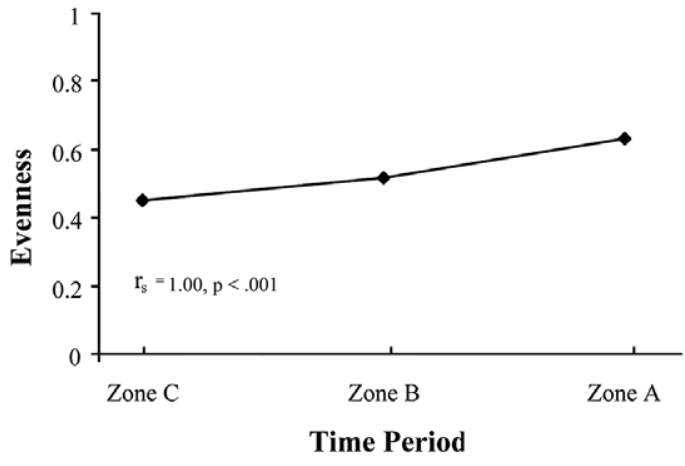

Figure 10. Prey evenness values for the entire assemblage, indicating an increase in evenness.

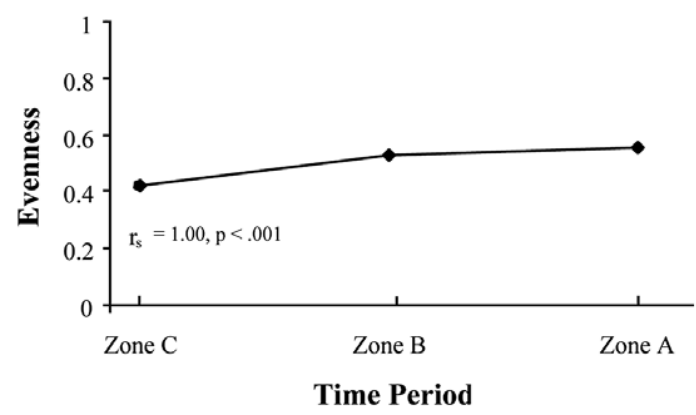

Figure 11. Prey evenness values for the coral reef patch, indicating an increase in evenness.

trast, the shoreline patch is stable, with evenness values fairly similar in all three zones $\left(r_{s}=0.5, P=.667\right.$ [Figure 12]).

A principal limitation of the use of evenness indices is that similar index values do not necessarily reflect similar resource use patterns. It is possible that proportional relationships between taxa stay the same while the taxa representing those proportions change (Nagaoka 2001). Analysis of prey rankings and relative abundances are necessary for a finer understanding of resource exploitation patterns. Inspection of the absolute abundances and comparative indices given here supports the results of the relative abundances and provides conclusive evidence for the trends discussed in this paper (Table 8).

Inspection of the relative shellfish abundances reveals a number of important trends. 


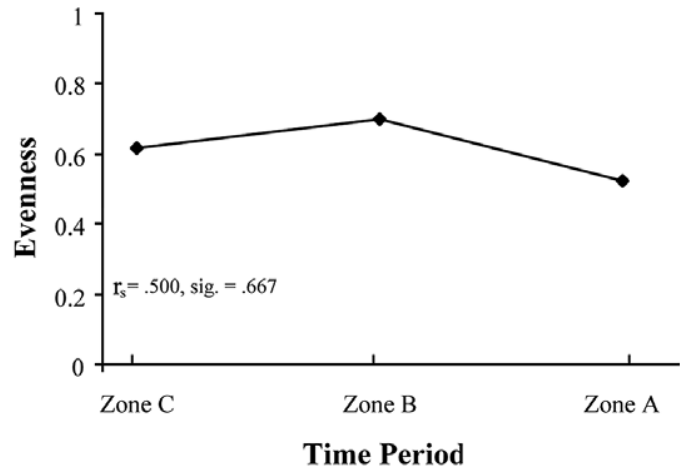

Figure 12. Prey evenness values for the shoreline patch, indicating stability in evenness.

First, the high-ranked Turbo sandwicensis decreases in abundance over time. Moreover, as Turbo sandwicensis decreases, other smaller, less-profitable prey increase. This is apparent in an increase in Strombus maculatus during the late prehistoric period. Moreover, both shoreline taxa Cellana spp. and Nerita picea also increase, but the coral reef species decrease.

Finally, the relative abundance measurements support the diet breadth and evenness analyses. For example, inspection of the proportional contribution of the five most common species demonstrates an increasingly greater contribution of other taxa to the total assemblage. The total percentage value for these five items decreases from $94.9 \%$ during the prehistoric to $84.5 \%$ during the protohistoric. Moreover, the relative percentage contribution of these prey items becomes more even through time.

\section{DISCUSSION}

The role of shellfish in the diet of past coastal dwellers has been the subject of debate among archaeologists (Yesner 1984, 1987, Claassen 1986, 1998, Erlandson 1988, 1991, 2001, Glassow and Wilcoxon 1988). In particular, the ability for mollusk species to sustain high-density human populations has received considerable attention in past years. For example, Claassen (1986, 1998) challenged the assertion that human predation led to substantial impacts on mollusk environments, except in cases of heavy exploitation in rocky shoreline habitats. In contrast, Swadling (1976, 1986), Botkin (1980), Anderson (1981), Jerardino (1997), Thomas and Mannino (1999, 2001), Mannino and Thomas (2001, 2002), and Thomas (2001) argued that sustained human exploitation can indeed severely affect mollusk populations. The results from Nu'alolo Kai complement those studies by providing evidence for human impacts on coral reef species while demonstrating stability in the use of shoreline mollusk communities.

In the coral reef habitat, the large Turbo sandwicensis decreased relative to the smaller Strombus maculatus, suggesting that as the encounter rate of $T$. sandwicensis declined, foragers relied more on smaller, abundant prey. A similar trend was also documented by Raab (1992), who used foraging theory to explain a shift in the exploitation of Haliotis spp. by inhabitants of San Clemente Island in southern California. Haliotis spp. or abalone are large mollusks that can be easily acquired. In contrast, Tegula spp. are smaller and more diffi-

TABLE 8

The Five Most Abundant Taxa (Percentages Shown in Parentheses)

\begin{tabular}{llll}
\hline \hline Rank & \multicolumn{1}{c}{ Zone A } & \multicolumn{1}{c}{ Zone B } & \multicolumn{1}{c}{ Zone C } \\
\hline 1 & Strombus maculatus (20.25\%) & Turbo sandwicensis (51.5\%) & Turbo sandwicensis (63.23\%) \\
2 & Turbo sandwicensis (18.56\%) & Strombus maculatus (26.19\%) & Strombus maculatus (17.68\%) \\
3 & Cellana sp. (16.2\%) & Isognomon sp. (8.1\%) & Isognomon sp. (6.8\%) \\
4 & Nerita picea $(15.52 \%)$ & Nerita picea $(3.0 \%)$ & Cellana sp. (4.0\%) \\
5 & Isognomon sp. (14.0\%) & Cellana sp. (2.9\%) & Nerita picea (3.2\%) \\
Total & $84.53 \%$ & $91.69 \%$ & $94.9 \%$ \\
\hline
\end{tabular}


cult to process. Raab suggested that the increased abundance of Tegula spp. and decreasing use of abalone is evidence for overexploitation.

The diversity analysis from $\mathrm{Nu}^{\text {'alolo Kai }}$ also demonstrates a general expansion of diet breadth by the protohistoric period. The number of taxa (NTAXA) foraged and evenness for the entire assemblage increase significantly through time, indicating a morediversified diet relying less on large mollusk species and more on an array of smaller prey. Similarly, at Palliser Bay, New Zealand, Anderson (1981) found that heavy predation pressure during prehistory led to a shift from a more-specific subsistence strategy focused on large shellfish species to wider diet breadth including smaller shellfish.

Botkin (1980) studied changes in the relative importance of Mytilus californianus and Protothaca staminea at the Malibu site along the southern California coast by looking at differences in the natural distribution and harvesting techniques of the two species. $\mathrm{He}$ reasoned that because $M$. californianus has a lower procurement cost and larger size than $P$. staminea it should dominate the earlier deposits. The archaeological evidence demonstrates that $M$. californianus was indeed heavily foraged during the early occupation period. A reversal in the relative abundance of these two species in later archaeological deposits suggests resource depression and overuse of M. californianus.

At Nu'alolo Kai, we assume that Turbo sandwicensis and Strombus maculatus had similar handling and procurement costs because there is no conclusive evidence to suggest that harvesting technologies were different for the two mollusk species. As a result, prey size at Nu'alolo Kai continues to be the best indicator of energetic return. Because harvesting technologies affect the overall return rate by decreasing energy spent acquiring and preparing items, capture and procurement techniques can ultimately have an effect on energetic return. Madsen and Schmitt (1998) suggested that researchers should pay more attention to technological innovations developed for the mass capture of smallbodied prey. Jones (2004, 2006) also noted that capture methods can affect the return rate of certain animals. In her archaeological study of prehistoric European rabbit (Oryctolagus cuniculus) hunting, Jones showed that the mass capture of rabbits through the use of warrens might have substantially increased the energetic return rate of these prey items.

Current research on the distribution of bird bone artifacts at Nu'alolo Kai (Esh 2005; K. S. Esh and A.E.M., unpubl. data) will prove useful for better understanding the relationship between technological innovation and the exploitation of certain marine species. In the past, bone artifacts have been interpreted as tools for extracting the fleshy meat of shellfish prey (Kirch 1985). If changes in the presence of bone tools can be securely tied to the extraction of mollusk meat, then the expansion of this technology may have increased the foraging return rates of less easily procured species. Research on these dynamic processes is needed to assess the relationship between Polynesian subsistence economies and the technological innovations documented by artifact distributions.

Recent ethnoarchaeological research on shellfish procurement processes and transport by Bird and Bliege Bird (1997, 2000) and Thomas (2002) highlights the potential biases when using the archaeological record to compare relative abundances of large and small mollusk species. Bird and Bliege Bird (1997, 2000) showed that among contemporary Meriam foragers of the Torres Strait, Australia, large mollusk species with low processing costs tend to be handled in the field to decrease travel time. In contrast, many smaller species with high procurement costs are often taken back to a base camp for processing (Bird and Bliege Bird 1997), and when children forage there is an increase in the number of small species gathered (Bird and Bliege Bird 2000). Thomas (2002:191) also suggested that "because resources often contain parts of high and low utility, other foraging models, such as prey choice, may not anticipate variability in archaeological assemblages: the mismatches between behavior and its archaeological correlates."

Although we are in agreement with Bird and Bliege Bird (1997, 2000) and Thomas 
(2002), we suggest that the problems associated with the nature of archaeological material do not negate the usefulness of foraging theory in the Nu'alolo Kai assemblage. Bird and Bliege Bird's research indicates that biases created by child foraging and differential field processing would create a more stable frequency of lower-ranked resources to higher-ranked ones. In contrast, "if intensification accounts for the differences, over time the introduction of lower ranked prey in the assemblage should correlate with a depression in higher ranked resources" (Bird and Bliege Bird 2000:472). Mannino and Thomas (2002:458) also noted that Bird and Bliege Bird's model "could account for the species composition of the latter midden deposits studied by both Anderson (1981) and Raab (1992), although it cannot explain why higher-ranked species dominated the earlier phases."

In our analysis we suggest that changes in the Nu'alolo Kai assemblage are more adequately explained by foraging intensification and resource depression rather than differential field processing, although the two are not mutually exclusive (see Cannon 2003). First, because we take multiple lines of evidence into consideration when testing for resource depression, we avoid the problems of making general conclusions based on the relative relationships of large- and small-bodied mollusks alone. Second, although documenting patterns in the largest and highest-ranked shellfish taxa in the prehistoric diet would ultimately facilitate our understanding of the overall temporal changes in the assemblage, our analysis is based on relative relationships of prey items already in the diet breadth. It is hard to see how differential field processing could result in any of the trends documented in our assemblage. For example, we demonstrate a significant decline in the abundance of the large gastropod Turbo sandwicensis correlated with an increase in the presence of the small Strombus maculatus. Differential field processing could indeed account for the increase in Strombus maculatus but fails to provide insight into the decreasing abundance of Turbo sandwicensis.
The changes demonstrated in the Nu'alolo Kai shellfish assemblage point to a few important issues. First, it seems likely that human-induced resource depression in the coral reef patch led to an increased use of the shoreline patch simply because the distribution of coral reef species declined and foragers exploited new areas and species. However, an alternative explanation is that gathering shoreline species may have required less time investment because of close proximity to habitation areas as well as their susceptibility to mass capture. Moreover, coral reef foraging may have been abandoned in favor of shoreline harvest to allocate more time to gardening and terrestrial resources. Allen $(1992,2002)$ argued on Aitutaki, Cook Islands, that when productive land became scarce, offshore fishing may have decreased to allocate more time to protecting agronomic plots, which included domesticated animals and gardens. A similar explanation might account for the switch from coral reef to shoreline harvesting at $\mathrm{Nu}^{\text {'alolo Kai. }}$

The trends documented in the Nu'alolo Kai mollusk assemblage are also important when viewed in combination with other predator-prey studies from the Pacific islands. A number of archaeological analyses have documented long-term human exploitation of nearshore reef fishes and mollusks that in many instances led to measurable environmental impacts (e.g., Swadling 1976, 1986, Anderson 1981, Spennenman 1987, Allen 1992, 2002, 2003, Kirch et al. 1995). It is probable that the decline in marine resources documented by those studies is also closely connected with other temporal changes in the overall Pacific island subsistence economy.

\section{CONCLUSION}

Evidence from our excavation and analysis at Nu'alolo Kai suggests that mollusk species, like other nearshore marine resources in the Pacific, were indeed susceptible to human overuse. Previous subsistence studies in $\mathrm{Ha}-$ wai' $i$ and Polynesia have emphasized the importance of mollusks and other inshore marine species in prehistoric diets as well as 
the role of environmental variability in structuring resource use patterns (e.g., Kirch 1982, 1985, Dye and Steadman 1990). Yet little research has focused specifically on how mollusk use varied through both space and time. By separating mollusk taxa by habitats, we are able to distinguish which species and habitats were more susceptible to human exploitation, as well as provide important supplementary records regarding resource use predating historical fisheries catch accounts. Because modern conservation of mollusk species in Hawaici continues to be an important concern for biologists (Gulko 2004, 2005, Meadows et al. 2005), our research has implications for applied habitat management.

Further studies on human impacts to nearshore environments in Hawai' $i$ and elsewhere in the Pacific should also take into consideration long-term patterns in inshore and offshore fish use. Data from a number of studies elsewhere in Oceania suggest that fishing in general decreased through time (Allen et al. 2001, Allen 2002, 2003, Fitzpatrick and Kataoka 2005). Currently, the timing and cause of this decline is not well understood; however it is plausible that overexploitation of wild varieties of shellfish and fish species might have led to increased dependency on more reliable and predictable terrestrial food resources (Kirch 1973, Fitzpatrick and Kataoka 2005). Although substantive data to test this hypothesis are indeed lacking for Hawai' $i$, the ongoing development of prey and patch choice models integrating the entire spectrum of subsistence strategies practiced across the archipelago will enhance the opportunity to examine subsistence change with a welldeveloped theoretical framework.

Finally, the results of our study show that human exploitation of shellfish follows a complex trajectory that affected the marine ecosystem at Nu'alolo Kai. The changes we detect are relatively subtle, suggesting that human predation did not have dramatic consequences such as wholesale resource depletion, extinctions, or habitat destruction. The complexity of change also argues for variability in cases of human predation and the impacts. Thus, it would be naive to generalize across marine environments in the Hawaiian Islands; instead, detailed archaeological histories of ecological variation will be essential.

\section{Literature Cited}

Allen, M. S. 1992. Dynamic landscapes and human subsistence: Archaeological investigations on Aitutaki Island, Cook Islands. Ph.D. diss., University of Washington, Seattle.

. 2002. Resolving long-term changes in Polynesian marine fisheries. Asian Perspect. 41 (2): 195-212.

- 2003. Human impact on Pacific nearshore marine ecosystems. Pages 317325 in C. Sand, ed. Pacific archaeology: Assessment and prospects (2003). Proceedings of the International Conference for the 50th Anniversary of the First Lapita Excavation, Koné, Nouméa, 2002. Les Cahiers de l'Archaéologie en Nouvelle Calédonie. Vol. 15. Service des Musées et du Patrimonie de Nouvelle-Calédonie, Nouméa.

Allen, M. S., T. N. Ladefoged, and J. J. Wall. 2001. Traditional Rotuman fishing in temporal context. Int. J. Osteoarchaeol. 11:5671.

Anderson, A. J. 1981. A model of prehistoric collecting on the rocky shore. J. Archaeol. Sci. 8:109-120.

Bird, D. W., and R. L. Bliege Bird. 1997. Contemporary shellfish gathering strategies among Meriam of the Torres Strait Islands, Australia: Testing predictions of a central place foraging model. J. Archaeol. Sci. 24:39-63.

- 2000. The ethnoarchaeology of juvenile foragers: Shellfish strategies among Meriam children. J. Anthropol. Archaeol. 19:461-476.

Botkin, S. 1980. Effects of human predation on shellfish populations at Malibu Creek, California. Pages 121-139 in T. K. Earle and A. L. Christenson, eds. Modeling change in prehistoric subsistence economies. Academic Press, New York.

Bronk Ramsey, C. 2005. OxCal program. v3.10. 
Broughton, J. M. 1994. Declines in mammalian foraging efficiency during the late Holocene, San Francisco Bay, California. J. Anthropol. Archaeol. 13:371-401.

. 2001. Resource intensification and late Holocene impacts on Pacific bird populations: Evidence from the Emeryville shellmound avifauna. Pages 251-279 in $\mathrm{T}$. L. Hunt, C. P. Lipo, and S. L. Sterling, eds. Posing questions for a scientific archaeology. Bergin and Garvey, Westport, Connecticut.

Butler, V. L. 2000. Resource depression on the northwest coast of North America. Antiquity 74:649-661.

-2001. Changing fish use on Mangaia, southern Cook Islands: Resource depression and the prey choice model. Int. J. Osteoarchaeol. 11:88-100.

Butler, V. L., and S. K. Campbell. 2004. Resource intensification and resource depression in the Pacific Northwest of North America. J. World Prehist. 18 (4): 327 405.

Butler, V. L., and M. G. Delacorte. 2004. Doing zooarchaeology as if it mattered: Use of faunal data to address current issues in fish conservation biology in Owens Valley, California. Pages 25-44 in R. L. Lyman and K. P. Cannon, eds. Zooarchaeology and conservation biology. University of Utah Press, Salt Lake City.

Byers, D. A., and J. M. Broughton. 2004. Holocene environmental change, artiodactyl abundances, and human hunting strategies in the Great Basin. Am. Antiq. 69:235-255.

Cannon, M. D. 2003. A model of central place forager prey choice and an application to faunal remains from the Mimbres Valley, New Mexico. J. Anthropol. Archaeol. 22:1-25.

Catterall, C. P., and I. R. Poiner. 1987. The potential impact of human gathering on shellfish populations with reference to some NE Australian intertidal flats. Oikos 50:114-122.

Charnov, E. L. 1976. Optimal foraging: The marginal value theorem. Popul. Biol. 9:129-136.

Claassen, C. 1986. Temporal patterns in ma- rine shellfish-species use along the Atlantic coast in the southeastern United States. Southeast. Archaeol. 5:120-137.

- 1998. Shells. Cambridge Manual in Archaeology, Cambridge, United Kingdom.

Cobb, J. N. 1905. The commercial fisheries. Pages 317-765 in D. S. Jordan and B. W. Evermann, eds. The aquatic resource of the Hawaiian Islands. Part II. Bull. U.S. Fish. Comm. 23.

Diamond, J. 2005. Collapse: How societies choose to fail or succeed. Viking Books, New York.

Dye, T., and D. W. Steadman. 1990. Polynesian ancestors and their animal world. Am. Sci. 78:207-215.

Erlandson, J. 1988. The role of shellfish in prehistoric economies: A protein perspective. Am. Antiq. 53:102-109.

- 1991. Shellfish and seeds as optimal resources: Early Holocene subsistence on the Holocene coast. Pages 89-101 in J. Erlandson and R. H. Colten, eds. Huntergatherers of Early Holocene coastal California. Perspectives in California Archaeology. Vol. 1. Institute of Archaeology, University of California, Los Angeles.

. 2001. Aquatic adaptations: Paradigms for a new millennium. J. Archaeol. Res. 9:287-350.

Erlandson, J., C. Rick Torben, R. Vellanoweth, and T. Largaespada. 2004. Human impacts on ancient environments: A case study from California's northern Channel Islands. Pages 51-83 in S. M. Fitzpatrick, ed. Voyages of discovery: The archaeology of islands. Praeger, New York.

Esh, K. S. 2005. Human impacts on Pacific seabirds: An analysis of resource use at Nu'alolo Kai, Kaua'i. M.A. thesis, University of Hawai'i at Mānoa, Honolulu.

Fitzpatrick, S. M., and O. Kataoka. 2005. Prehistoric fishing in Palau, Micronesia: Evidence from the Northern Rock Islands. Archaeol. Oceania 40:1-13.

Glassow, M. A., and L. R. Wilcoxon. 1988. Coastal adaptations near Point Conception California, with particular regard to shellfish exploitation. Am. Antiq. 53:36-51.

Graves, M. W., J. M. Field, and W. K. 
McElroy. 2005. An overview of site 50-3001-196, Nu'alolo Kai, Kaua'i: Features, excavation, stratigraphy, and chronology of historic and prehistoric occupation. Pages 149-187 in M. T. Carson and M. G. Graves, eds. Na Mea Kahiko o Kaua'i: Archaeological studies in Kaua'i. Special Publication No. 2, Society for Hawaiian Archaeology, Honolulu, Hawai'i.

Grayson, D. 1984. Quantitative zooarchaeology: Topics in the analysis of archaeological faunas. Academic Press, New York. 2001. The archaeological record of human impacts on animal populations. J. World Prehist. 15 (1): 1-68.

Grayson, D., and F. Delpech. 1998. Changing diet breadth in the Early Upper Paleolithic of southwestern France. J. Archaeol. Sci. 25:1119-1129.

Gulko, D. 2004. Hawaiian marine species for ESA Candidate listing revised Candidate list. State of Hawai'i Division of Aquatic Resources, Honolulu.

- 2005. Hawaii endemic species status chart spreadsheet. State of Hawai'i Division of Aquatic Resources, Honolulu.

Hawai'i Department of Land and Natural Resources. 1981. Protected marine fisheries resources. Chapter 92, "Opihi." In State of Hawai'i Administrative Rules, Honolulu.

Hildebrandt, W. R., and T. L. Jones. 1992. The evolution of marine mammal hunting: A view from the California and Oregon coasts. J. Anthropol. Archaeol. 11:360-401.

Hunt, T. L. 2005. Archaeological stratigraphy and chronology at $\mathrm{Nu}^{\text {'alolo }} \mathrm{Kai}, \mathrm{Na}$ Pali District, Kaua'i. Pages 236-258 in M. T. Carson and M. G. Graves, eds. Na Mea Kahiko o Kaua'i: Archaeological studies in Kaua'i. Special Publication No. 2 Society for Hawaiian Archaeology, Honolulu, Hawa'i.

Jackson, J. B. C. 2001. What was natural in the coastal oceans? Proc. Natl. Acad. Sci. U.S.A. 98:5411-5418.

Jackson, J. B. C., M. X. Kirby, W. H. Berger, K. A. Bjorndal, L. W. Botsford, B. J. Bourque, R. H. Bradbury, R. Cooke, J. Erlandson, J. A. Estes, T. P. Hughes, S. Kidwell, C. B. Lange, H. S. Lenihan, J. M. Pan- dolfi, C. H. Peterson, R. S. Steneck, M. J. Tegner, and R. R. Warner. 2001. Historical overfishing and the recent collapse of coastal ecosystems. Science (Washington, D.C.) 293:629-637.

Jerardino, A. 1997. Changes in shellfish species composition and mean shell size from a late Holocene record of the west coast of Southern Africa. J. Archaeol. Sci. 24:10311044.

Jones, L. E. 2004. Broad spectrum diets and the European rabbit (Oryctolagus cuniculus): Dietary change during the PleistoceneHolocene transition in the Dordogne, southwestern France. Ph.D. diss., University of Washington, Seattle.

. 2006. Prey choice, mass collecting, and the wild European rabbit (Oryctolagus cuniculus). J. Anthropol. Archaeol. 25:275289.

Kay, A. 1979. Hawaiian marine shells. Reef and Shore Fauna of Hawaii, Section 4: Mollusca. Bernice P. Bishop Musem Press, Honolulu, Hawai' $i$.

Kay, A., and W. Magruder. 1977. The biology of opihi. Department of Planning and Development, State of Hawai'i, Honolulu.

Kirch, P. V. 1973. Prehistoric subsistence patterns in the northern Marquesan Islands, French Polynesia. Archaeol. Phys. Anthropol. Oceania 8:24-40.

- 1982. The ecology of marine exploitation in prehistoric Hawaii. Hum. Ecol. 10:455-476.

. 1985. Feathered gods and fishhooks: An introduction to Hawaiian archaeology and prehistory. University of Hawai'i Press, Honolulu.

- 1997. Microcosmic histories: Island perspectives on global change. Am. Anthropol. 99 (1): 30-42.

Kirch, P. V., D. W. Steadman, V. L. Butler, J. Hather, and M. I. Weisler. 1995. Prehistory and human ecology in eastern Polynesia: Excavations at Tagatatu rockshelter, Mangaia, Cook Islands. Archaeol. Oceania 30:47-65.

Kirch, P. V., and D. Yen. 1982. Tikopia: Prehistory and ecology of a Polynesian outlier. Bernice P. Bishop Mus. Bull. 238. 
Lyman, R. L. 2003. Pinneped behavior foraging theory and the depression of metapopulations and non-depression of a local population on the southern northwest coast of North America. J. Anthropol. Archaeol. 22:376-388.

Lyman, R. L., and K. P. Cannon. 2004. Zooarchaeology and conservation biology. University of Utah Press, Salt Lake City.

Madsen, D. B., and D. N. Schmitt. 1998. Mass collecting and the diet breadth model: A Great Basin example. J. Archaeol. Sci. 25:445-455.

Mannino, M. A., and K. D. Thomas. 2001. Intensive Mesolithic exploitation of coastal resources? Evidence from a shell deposit on the Isle of Portland (southern England) for the impact of human foraging on populations of intertidal rocky shore mollusks. J. Archaeol. Sci. 28:1101-1114.

. 2002. Depletion of a resource? The impact of prehistoric human foraging on intertidal mollusk communities and its significance for human settlement mobility and dispersal. World Archaeol. 33:452474.

McAllister, A. 2003. Prehistoric fishing at Fakaofa Atoll, Tokelau. M.A. thesis, University of Auckland, Auckland, New Zealand.

Meadows, D., A. L. Kane, C. Mitchell, and C. Ogura. 2005. Technical Report X. Hawai'i Statewide Aquatic Wildlife Conservation Strategy. Pacific Cooperative Studies Unit, University of Hawaíi at Mānoa, Honolulu.

Nagaoka, L. 2001. Using diversity indices to measure changes in prey choice at the Shag River Mouth site, southern New Zealand. Int. J. Osteoarchaeol. 11:101-111.

. 2002. The effects of resource depression on foraging efficiency, diet breadth and patch choice use in southern New Zealand. J. Anthropol. Archaeol. 21:419442.

Orians, G. H., and N. E. Pearson. 1979. On the theory of central place foraging. Pages 154-177 in D. J. Horn and R. D. Mitchell, eds. Analysis of ecological systems. Ohio State University Press, Columbus.

Pianka, E. R. 1983. Evolutionary ecology. Harper and Row, New York.
Raab, M. 1992. An optimal foraging analysis of prehistoric shellfish collecting on San Clemente Island, California. J. Ethnobiol. 12:63-80.

Reimer, P. J., M. G. L. Baillie, E. Bard, A. Bayliss, J. W. Beck, C. Bertrand, P. G. Blackwell, C. E. Buck, G. Burr, K. B. Cutler, P. E. Damon, R. L. Edwards, R. G. Fairbanks, M. Friedrich, T. P. Guilderson, K. A. Hughen, B. Kromer, F. G. McCormac, S. Manning, C. Bronk Ramsey, R. W. Reimer, S. Remmele, J. R. Southon, M. Stuiver, S. Talamo, F. W. Taylor, J. van der Plicht, and C. E. Weyhenmeyer. 2004. IntCal04 Terrestrial radiocarbon age calibration, 26-0 ka BP. Radiocarbon 46:1029-1058.

Reitz, E. J. 2004. "Fishing down the web": A case study from St. Augustine, Florida, USA. Am. Antiq. 69:63-83.

Severns, M. 2001. Hawaiian seashells. Island Heritage, Hawai'i.

Smith, E. A. 1991. Injuamiuat foraging strategies: Evolutionary ecology of an Artic hunting economy. Aldine De Gruyter, New York.

Smith, E. A., and M. Wishnie. 2000. Conservation and subsistence in small scale societies. Annu. Rev. Anthropol. 29:493-524.

Spennenman, D. H. R. 1987. Avaliability of shellfish resources on prehistoric Tongatapu, Tonga: Effects of human predation and changing environment. Archaeol. Oceania 22:81-96.

Steneck, R. S., J. Vavrinec, and A. V. Leland. 2004. Accelerating trophic-level dysfunction in kelp forest ecosystems of the western North Atlantic. Ecosystems 7:323332.

Stephens, D. W., and J. R. Krebs. 1986. Foraging theory. Princeton University Press, Princeton, New Jersey.

Swadling, P. 1976. Changes induced by human predation in prehistoric shellfish populations. Mankind Q. 10:156-162.

. 1986. Lapita shellfishing: Evidence from sites in the Reef/Santa Cruz Group, Southeast Solomons. Pages 137-148 in Traditional fishing in the Pacific. Anthropological Records 37. Bernice P. Bishop Museum, Honolulu, Hawai'i. 
Thomas, F. R. 2001. Mollusk habits and fisheries in Kiribati: An assessment from the Gilbert Islands. Pac. Sci. 55:77-97.

- 2002. An evaluation of central place foraging among mollusk gathers in western Kiribati, Micronesia: Linking behavior ecology with ethnoarchaeology. World Archaeol. 34:182-208.

Thomas, K. D., and M. A. Mannino. 1999. The bioarchaeology of the Culverwell shell midden. Pages 94-114 in S. Palmer. Culverwell Mesolithic site habitation site, Isle of Potland: Excavation report and research studies. Archaeological Reports, Oxford, United Kingdom. . 2001. The exploitation of invertebrates and invertebrate products. Pages 427-440 in D. R. Brothwell and A. M. Pollard, eds. Handbook of archaeological sciences. Willey, Chichester, United Kingdom.

Ugan, A. 2005. Climate, bone density, and resource depression: What's driving variation in large and small game in Fremont archaeofaunas? J. Anthropol. Archaeol. 24:227-251.
Wing, S. R., and E. S. Wing. 2001. Prehistoric fisheries in the Caribbean. Coral Reefs 20:1-8.

Winterhalder, B. 1981. Foraging strategies in the boreal forest: An analysis of Cree hunting and gathering. Pages 66-98 in B. Winterhalder and E. A. Smith, eds. Hunter-gatherer foraging strategies. University of Chicago Press, Chicago.

Wolverton, S. 2005. The effects of the hypsithermal on prehistoric foraging in Missouri. Am. Antiq. 70:91-106.

Woodward. C. S. 2000. Ocean's end: Travels through endangered seas. Basic Books, New York.

Yesner, D. R. 1984. Population pressure in coastal environments: An archaeological test. World Archaeol. 16:108-127.

. 1987. Life in the 'Garden of Eden': Causes and consequences of the adoption of marine diets by human societies. Pages 285-310 in M. Harris and E. B. Ross, eds. Food and human evolution: Towards a theory of food and human habits. Temple University Press, Philadelphia, Pennsylvania. 
